\title{
OBRAZ ŚW. HILDEGARDY Z BINGEN W KULTURZE WSPÓŁCZESNEJ
}

JOANNA TARNAWSKA Wydział Nauk Humanistycznych Uniwersytet Kardynała Stefana Wyszyńskiego; Faculty of Humanities Cardinal Stefan Wyszyński University in Warsaw (Poland). joanna.tarnawska@gmail.com

\section{JAK KULTURA POPULARNA WYKORZYSTUJE WIZERU- NEK I NAUKI HILDEGARDY}

W czasach, gdy pytanie o sens zajmuje coraz bardziej centralne miejsce, Hildegardy całościowe spojrzenie na Boga, człowieka i kosmos może niejednemu pomóc znaleźć odpowiedź ${ }^{1}$.

Medycyna dla kobiet, Przyrodolecznictwo, Książki kucharskie Hildegardy czy poradniki zdrowego życia według Hildegardy - to najczęstsze publikacje z naukami świętej. Biografie czy książki na temat muzyki, filozofii lub teologii znajdujemy raczej w księgarniach chrześcijańskich. W sklepach muzycznych możemy dokonać wyboru pomiędzy nagraniami zespołów muzyki dawnej, które próbują odtworzyć oryginalną muzykę Hildegardy, a grupami muzycznymi, dla których Hildegarda jest inspiracją do tworzenia muzyki elektronicznej i New Age². Twórczość i nauki benedyktynki są tematem koncertów, festiwali muzycznych i ekologicznych, audycji radiowych,

${ }^{1}$ H. Hinkel, Hildegard von Bingen. Nachleben, [w:] Hildegard von Bingen 10981179, red. H.-J. Kotzur, Mainz 1998, s.152-153.

${ }^{2}$ Muzyka New Age - muzyka inspirująca się ruchem New Age, często elektroniczna i instrumentalna, ale i wokalna. Muzyka mająca na celu wprowadzić słuchacza w trans, opróżnić jego umysł, by mógł się zbliżyć do istot duchowych. 
wystaw, sztuki performatywnej, warsztatów zdrowego trybu życia, rekolekcji czy wykładów. W wielu sklepach internetowych na całym świecie możemy kupić produkty etykietowane Hildegardą, zaczynając od wafli i herbat, a kończąc na kremach i biżuterii³ .

Skąd i kiedy przyszła moda na Hildegardę? Za życia mistyczka była dla wielu autorytetem, po jej śmierci to się niestety zmieniło. Wielcy teologowie z XIII i XIV wieku, jak Albert Wielki, Tomasz z Akwinu, Bonawentura, Jans Duns Szkot, Bacon, nie wspominają o niej ani nie korzystają z jej pism. Nie znajdziemy jej także w trzynastowiecznym piśmiennictwie kaznodziejskim czy nawet w pismach mistycznych kobiet tego okresu. Hildegarda była za to silnie atakowana za swoje poglądy przez zakony żebracze.

Era druku przypomniała jej postać. W Polsce już w 1640 roku Franciszek Cezary wydał przekład Żywotu św. Hildegardy, jego autorem był ks. Wojciech Dziedzic ${ }^{4}$. Dopiero wiek XIX zainteresował się ponownie Hildegardą. Okres badań nad średniowiecznym piśmiennictwem kobiet, a tym samym nad twórczością Hildegardy zapoczątkował w 1984 roku Peter Dronke monografią Woman writers of the Middle Ages. Dzieła mniszki i ona sama stały się obiektem wielu analiz. Powstawały nie tylko reedycje pism, biografie, analizy naukowe, lecz także publikacje pseudonaukowe, które często przekształcały myśl Hildegardy na własne potrzeby. Ilość bibliografii była tak duża, że w artykule w 1998 roku K. Flash napisał: Haende weg von Hildegard! (Ręce precz od Hildegardy!) . Według badaczy, poprzez tak różne kierunki zainteresowania Hildegardą: od teologii, muzyki, medycyny, a skończywszy na książkach kucharskich, współczesny człowiek ma utrudniony dostęp do

\footnotetext{
${ }^{3}$ Patrz: fotografia nr 1 .

${ }^{4}$ M. Malicki, Repertuar wydawniczy drukarni Franciszka Cezarego starszego 1616-1651. Cz. 1. Bibliografia druków Franciszka Cezarego Starszego 1616-1651, Kraków 2010, hasło: Hildegarda - nr 482.

5 J. Strzelczyk, Przedmowa, [w:] Hildegarda, Scivias, thum. J. ŁukaszewskaHaberkowa, Tyniec 2011, s.12.
} 
świata benedyktynki. Jerzy Strzelczyk porusza kwestię braku ,właściwego dostępu”. Tym samym rodzi się pytanie, czym jest ten właściwy dostęp? Czy należy zanegować każdy inny przejaw zainteresowania Hildegardą niż teologiczny i naukowy? Czy prawo do Hildegardy należy się tylko teologom i badaczom akademickim?

Hildegarda jako pierwsza znana nam kompozytorka w historii muzyki stała się inspiracją dla wielu muzyków. To zespół Sequentia zainteresował się nią na początku lat 80 . i spopularyzował jej twórczość ${ }^{6}$. Grupa podjęła się ogromnie trudnego zadania: wykonała wszystkie zachowane dzieła mniszki. Dostępnych jest siedem wydań albumowych z dziewięćdziesięcioma jeden utworami, w tym nagranie muzycznego dramatu Ordo Virtutum ${ }^{7}$. Jeden z nich, Canticles of Ecstasy, zdobył kilka międzynarodowych nagród (Edison Price, Disque d'Or oraz nominacje do nagrody Grammy za najlepsze nagranie chorału). Na całym świecie sprzedano ponad pół miliona tych płyt. Zespół nieustannie koncertuje i tworzy nowe nagrania.

Innym przykładem inspiracji muzyką mniszki jest twórczość Marie-Luise Hinrichs. Dokonała ona rzeczy niezwykłej. Niemiecka pianistka transkrybowała chorałową muzykę Hildegardy na romantyczny fortepian. Połączyła dwa przeciwstawne sobie style epoki średniowiecza i romantyzmu. Tak powstała jedyna w swoim rodzaju płyta Vocation ${ }^{8}$. Zamiana ludzkiego głosu na fortepian nie zmieniła duchowego charakteru muzyki. Mimo że nie usłyszymy tu pierwotnej harmoniczności, pianistka wyśpiewała każdą nutę, posługując się doskonale pianem i pauzami. Dzięki nieschematycznemu

\footnotetext{
${ }^{6}$ Jeden z najsłynniejszych zespołów specjalizujących się w muzyce średniowiecza oraz równocześnie prowadzący badania muzykologiczne. Grupa powstała w Bazylei w 1977 roku z inicjatywy Benjamina Bagby i Barbary Thornton, < $\underline{\text { http:// }}$ www.sequentia.org>, [data dostępu: 4.04.13].

${ }^{7}$ Sequentia, Hildegarda von Bingen [CD-ROM], Sony Music Entertainment, 2011.

${ }^{8}$ Marie-Louise Hinrich, Vocation. Hildegard von Bingen [CD-ROM], Niemcy 2009.
} 
myśleniu pianistki, średniowieczna muzyka stała się bardziej zrozumiała dla dzisiejszego słuchacza i bliższa mu.

Płyta Hildegard. Hildegard von Bingen ${ }^{9}$ to następny innowacyjny projekt. Twórcy płyty zremiksowali muzykę Hildegardy i dodali do niej dźwięki elektroniczne. Dzięki subtelności i oszczędności przetworzonych elektronicznie tonów zderzenie chorału z muzyką elektroniczną na szczęście nie tworzy efektu kiczu. Kompozycje te nadal zachowują pierwotną koncepcję muzyki Hildegardy (muzyka jako odbicie kosmosu), choć w wersji ,ambient”"10.

Twórcy muzyki New Age czy tak zwanej muzyki relaksacyjnej także zainteresowali się utworami Hildegardy. Jednak tym razem, np. na płycie Vision, ${ }^{11}$ dodano kilka instrumentów: gitary, bębny, grzechotki, cymbałki, wzbogacone o dźwięki elektroniczne. Całość niestety jest tylko skomercjalizowaną podróbką oryginalnej muzyki mistyczki. Duża liczba instrumentów zagłusza prostotę pieśni Hildegardy. Jest to doskonały przykład na to, jak kultura masowa przetwarza dzieło wymagające refleksji i skupienia na łatwo sprzedający się produkt.

W Polsce twórczością Hildegardy zajęła się jak dotąd zapewne jedynie sopranistka Dorota Bonisławska, specjalizująca się w muzyce sakralnej i oratoryjnej. Artystka wydała płytę z dziewięcioma utworami świętej. Album nosi tytuł Caritas abundat ${ }^{12}$. Na płycie znajduje się także osiem tekstów recytowanych przez Dariusza Biernackiego. W trzech utworach słyszymy gitarę basową Andrzeja Stodulskiego.

Chociaż na polskim rynku jest dostępny tylko jeden album z polską interpretacją muzyki Hildegardy, nie możemy narzekać na brak koncertów. W roku 2012 odbyło się ich kilka, w różnych częściach Polski. Były to nie

${ }^{9}$ S. Wishart, Hildegard. Hildegard von Bingen [CD-ROM], Decca Records 2012.

${ }^{10}$ Ambient - gatunek muzyki elektronicznej.

${ }^{11}$ R. Souther, Vision.The Music of Hildegard von Bingen [CD-ROM], Angel Records 1994.

${ }^{12} \mathrm{Z}$ łac. Miłość obfituje. 
tylko koncerty, które starały się odtworzyć dzieła Hildegardy, lecz także widowiska muzyczne inspirujące się twórczością mniszki.

Młode pokolenie artystów również czerpie inspiracje $\mathrm{z}$ twórczości Hildegardy. Anna Zaradny - artystka dźwiękowa i wizualna oraz kompozytorka, stworzyła w 2011 roku dźwiękową instalację performatywną zatytułowaną Najsłodszy dźwięk krążącego firmamentu. Instalacja, współfinansowana przez m.st. Warszawa, przybrała kształt ogromnej dźwiękowej mandali. Można ją było zobaczyć w Komunie Warszawskiej ${ }^{13}$. Artystka o swoim projekcie mówiła: „Odwzorowuję idee średniowiecznej artystki własnym językiem, w którym porządek i harmonia rzeczy nie są już tak jednoznaczne"14.

W 2009 roku powstał jedyny jak dotychczas film o Hildegardzie: Wizja $z$ życia Hildegardy z Bingen, wyreżyserowany przez Niemkę - Margarette von Trotte ${ }^{15}$. Główną rolę zagrała Barbara Sukowa. Podobno reżyserka już od lat 80. nosiła się z zamiarem zrealizowania tego obrazu, jednak wyreżyserowanie filmu o średniowiecznej benedyktynce nie należało do najłatwiejszych zadań. Dzieło zachwyca pięknymi, kolorystycznie chłodnymi zdjęciami, które znakomicie oddają atmosferę tamtego czasu. W filmie dominują obrazy zimnych i półmrocznych pomieszczeń zakonnych. Widz może na własne oczy zobaczyć, co znajduje się za murami klasztoru. Artystka stworzyła postać Hildegardy silnej, pełnej energii, chwilami bardzo surowej, ale odważnej i owianej tajemniczością. W Wizji z życia Hildegardy z Bingen brakuje paradoksalnie opisów i obrazów samych widzeń. Za to niepotrzebnie

${ }^{13}$ Komuna Warszawska - stowarzyszenie działające w dziedzinie kultury i sztuki, organizujące spektakle, happeningi, wystawy, kampanie społeczne i ekologiczne. Siedziba: ul. Lubelska 30/32, Warszawa

${ }^{14}$ Anna Zaradny, Najsłodszy dźwięk krążacego firmamentu, <http://komuna.warszawa.pl/2011/11/28/anna-zaradny-\%E2\%80\%9Enajslodszy-dzwiek-krazacego-firmamentu $\% \mathrm{E} 2 \% 80 \% 9 \mathrm{D} />$, [data dostępu: 4.04.13].

${ }^{15}$ M. von Trotte, Vision - Aus dem Leben der Hildegard von Bingen, Niemcy 2009. 
został rozbudowany wątek burzliwej relacji Hildegardy z Ryszardą. Święta ukazana została tutaj jako osoba zaborcza i histeryczna. Jest to oczywiście fikcja filmowa, gdyż o relacji z Ryszardą mamy bardzo mało informacji. Reżyserka starała się raczej pokazać kontakty Hildegardy z innymi ludźmi, przedstawić ją bardziej jako człowieka niż jako mistyczkę. Film jednak w ogromnej mierze opiera się na źródłach historycznych. W trakcie pracy nad obrazem Margarette von Trotte studiowała biografie mniszki, jej dzieła i listy.

Powrót fascynacji medycyną Hildegardy nastąpił dopiero w 1910 roku. Wtedy to w Bibliotece Królewskiej w Kopenhadze znaleziono jedyny odręcznie napisany egzemplarz podręcznika Hildegardy - Causae et curae, opisujący przyczyny i metody leczenia chorób. W roku 1932 Hugon Schultz opublikował go w całości po niemiecku, jednak dopiero Gottfried Hertzka posłużył się nim, aby stworzyć nową medycynę naturalną - medycynę Hildegardy ${ }^{16}$.

Prężnym ośrodkiem w Polsce zajmującym się od kilku lat popularyzowaniem wiedzy o Hildegardzie jest Benedyktyński Instytut Kultury w Tyńcu. W ramach V Dni Benedyktyńskich, które miały miejsce w 2011 roku, odbyły się tam konferencje naukowe i teologiczne poświęcone Hildegardzie. Do udziału w nich zostali zaproszeni goście z Polski i Niemiec. Instytut Benedyktyński zorganizował także w tym samym roku wystawę zatytułowaną: Jak piórko wiatrem niesione... Świat Hildegardy z Bingen. Wirtualna podróż medytacyjna przez dzieje zbawienia. Wystawa była poświęcona wizjom Hildegardy, a świat benedyktynki został zaprezentowany odbiorcom w wersji multimedialnej. W salach muzeum można było oglądać średniowieczne miniatury w wersji animowanej, wokół zaś rozbrzmiewały mistyczne utwory mniszki. Celem twórców wystawy było z jednej strony przybliżenie postaci samej Hildegardy, a z drugiej - zaproszenie widza do

${ }^{16}$ W. Strehlow, Wiedza..., op. cit., s. 7. 
zatrzymania się i zastanowienia nad harmonią świata opisywaną przez tę mistyczkę ${ }^{17}$.

Benedyktyński Instytut Kultury w Tyńcu kilka razy w roku organizuje warsztaty i rekolekcje z naukami Hildegardy. Warsztaty prowadzi dr teologii Elżbieta Wiater, autorka biografii świętej, oraz teolog o. Szymon Hiżycki. O warsztatach tych możemy przeczytać na stronie internetowej:

Podczas warsztatów zajmiemy się odnajdywaniem w sobie harmonii, o której mówi Hildegarda. Uczestnicy będą odkrywać własny rytm życia i integrację przez proste ćwiczenia ruchowe, malowanie (nie trzeba mieć umiejętności artystycznych) oraz medytację chrześcijańską. Odnalezienie i doświadczenie w sobie tych samych sił, które poruszają kosmosem, pomaga w lepszym poznaniu samego siebie, drugiego człowieka, a to z kolei może stać się dyskretnym zaproszeniem do duchowej przygody i otwarcia się na łaskę Boga. Do praktykowania poznawania samego siebie zachęca Hildegarda: „Poznaj siebie, pokonuj obciążenia, pielęgnuj cnoty chrześcijańskie, aby uzyskać zdrowie duchowe i fizyczne”. Będzie też okazja do zapoznania się z postacią św. Hildegardy podczas wykładu autorki książki o św. Hildegardzie, Elżbiety Wiater, oraz poznania kontekstu filozoficznego podczas konferencji o. dr Szymona Hiżyckiego osb ${ }^{18}$.

W Tyńcu możemy skorzystać także z kilkudniowych rekolekcji z postem św. Hildegardy. Rekolekcje składają się z kilku elementów: diety (w której skład wchodzą orkisz, wywary warzywne i owocowe, herbaty ziołowe, napoje, a także przyprawy przygotowane według receptur św. Hildegardy), codziennych wykładów z zakresu nauki św. Hildegardy oraz z poszukiwania harmonii ducha - poprzez codzienną Mszę Świętą, medytację i możliwość skorzystania ze spowiedzi. Oprócz tego uczestnicy rekolekcji wychodzą na spacery

${ }^{17}$ Świat Hildegardy z Bingen- niezwykła ekspozycja, $<$ http://www.tyniec.benedyktyni.pl/videorelacje/swiat-hildegardy-z-bingen-niezwykla-ekspozycja.html>, [data dostępu: 05.04.13].

${ }^{18}$ Kosmos świętej Hildegardy, <http://www.benedyktyni.eu/?page id=6293 $>$, [data dostępu: 10.04.13]. 
i wycieczki, by korzystać ze świeżego powietrza oraz rezygnują z alkoholu, kawy i leków, których zażywanie nie jest konieczne. W trakcie postu każdy ma możliwość odbycia rozmowy z mnichem. „Post wg św. Hildegardy służy leczeniu zarówno duszy, jak i ciała. Właściwie przeprowadzony, w sposób łagodny i bezpieczny oczyszcza ciało i duszę przy zachowaniu pełnej witalności, dobrego samopoczucia i nastroju bez odczucia głodu"19.

Polskie Centrum Hildegardy z siedzibą w Legnicy oraz Centrum św. Hildegardy w Józefowie prowadzą podobną działalność. Pierwsze z nich założyła Alfreda Walkowska, doktorantka Papieskiego Wydziału Teologicznego we Wrocławiu, jedyna dyplomowana terapeutka medycyny Hildegardy w Polsce. Zainicjowała ona także powstanie polskiego towarzystwa pod nazwą Krąg Przyjaciół św. Hildegardy. Od 1992 roku popularyzuje wiedzę o Hildegardzie i jej dziełach. Instytucja ta organizuje w ciągu roku warsztaty żywieniowe, rekolekcje, odpoczynek z naukami świętej. Centrum prowadzi własną stronę internetową, na której można przeczytać o osobie Hildegardy, o jej programie zdrowia, o kulcie Hildegardy oraz uzyskać informacje na temat najbliższych spotkań z nią związanych, a także o nowościach wydawniczych na jej temat. W Internecie znajdziemy także link do sklepu z produktami etykietowanymi Hildegardą. Widnieją w nim książki, płyty, obrazy, orkisz, przyprawy z apteki św. Hildegardy, wina ${ }^{20}$ od św. Hildegardy, napoje przyrządzane według receptury Hildegardy, herbaty, migdały, ciasteczka orkiszowe, przyprawy do wypieków i konfitur, wyroby borsucze (wkładki skórzane borsucze, pantofle i pas z włosiem borsuczym), kosmetyki (kremy fiołkowe, macierzankowe, wody różane, winogronowe, fiołkowe, liliowe, maseczki lawendowe, ziołowe pasty do zębów ${ }^{21}$, antycelullitowe kremy

${ }^{19}$ Rekolekcje z postem św. Hildegardy, <http://www.benedyktyni.eu/?page $\underline{\mathrm{id}=478}>$, [data dostępu: 13.04.13].

${ }^{20}$ Patrz: fotografia $\mathrm{nr} 2$.

${ }^{21}$ Patrz: fotografia $\mathrm{nr} 3$. 
z szałwii ${ }^{22}$ oraz płyny śliwkowe do pielęgnacji ciała i włosów). Oprócz tego W sklepie możemy kupić biżuterię i różańce zrobione z kamieni ${ }^{23}$. Duża część produktów ze sklepu ma ścisły związek z naukami Hildegardy, jednak przeglądając ofertę można znaleźć także ketczup, sos chili, czekolady, chipsy kokosowe lub żelki - misie bio. Jednym słowem, Hildegarda stała się symbolem zdrowego jedzenia. Można powiedzieć, że została przejęta przez kulturę zdrowego życia, która jest tak popularna od kilkunastu lat. Dla wielu producentów stała się dobrze sprzedającym się produktem konsumpcyjnym.

Oprócz sklepu ze zdrową żywnością Hildegardy w Legnicy rozwija się kult świętej. W kościele Najświętszego Serca Jezusa wisi obraz Hildegardy, który odbył pielgrzymkę do Bingen. Raz w miesiącu po Mszy Świętej odprawiane są nabożeństwa ku czci Hildegardy. Po modlitwach wierni spotykają się na herbatce i ciasteczkach orkiszowych.

Drugą instytucją zajmująca się zdrowym sposobem życia jest Centrum Hildegardy w Józefowie, otwarte w 2012 roku. Oprócz sklepu z produktami $\mathrm{z}$ wizerunkiem świętej prowadzi ono gabinet, w którym oferuje pomoc terapeutów - specjalistów medycyny Hildegardy. W sklepie interesujący jest „zestaw postny”, a w nim: zupa, ciasteczka, koper włoski, tabletki z pigwy ${ }^{24}$. Ponadto samo centrum i nauki Hildegardy są reklamowane przez znaną w mediach aktorkę Małgorzatę Kożuchowską, co świadczy o coraz większej popularności świętej.

Choć Hildegarda nigdy nie napisała żadnej książki kucharskiej, to od kilku lat powstaje mnóstwo pozycji takich jak Książa kucharska Hildegardy, Kuchnia św. Hildegardy, Dieta i post wedtug Hildegardy. Autorzy tych

\footnotetext{
${ }^{22}$ Patrz: fotografia $\mathrm{nr} 4$.
}

${ }^{23}$ Hildegarda zajmowała się sztuką leczenia szlachetnymi kamieniami. Uważała, że każdy kamień ma określone drgania, które mogą być przenoszone przez skórę lub organy zmysłów na człowieka. Zob.: W. Strehlow, Wiedza ..., op. cit., s. 325.

${ }^{24}$ Centrum świętej Hildegardy w Józefowie, <http://centrum-hildegarda.pl>, [data dostępu: 13.04.13]. 
wszystkich książek korzystają z medyczno-przyrodniczych dzieł mniszki, opisując sposób leczenia za pomocą odpowiedniej żywności (warzyw, ziół, ziaren). Lekarz zajmujący się medycyną Hildegardy, dr Wighard Strehlow, oparł swoje prace na wieloletnich praktykach i badaniach. W Allensbach nad jeziorem Bodeńskim prowadzi prywatną klinikę Hildegard-Zentrum Bodensee.

Warto jeszcze raz podkreślić, że z duchowości i wiedzy Hildegardy korzystają nie tylko chrześcijanie, lecz także wyznawcy New Age. Hildegarda jest dla nich bioenergoterapeutką. Występujące w jej pismach słowo Światłość interpretują nie jako osobowego Boga, lecz pierwotne doświadczenie religijne, które ma leżeć u podstaw wszystkich religii. Zapominają jednak, że Hildegarda zawsze pisała o chrześcijańskim Bogu. Jedność kosmosu, świata i Boga nie funkcjonuje u niej na zasadzie tożsamości, lecz współbrzmienia. To jest zasadnicza różnica pomiędzy chrześcijaństwem a ideologią New Age.

W Internecie (na stronie www.zagrozeniaduchowe.pl) znajdziemy tekst, który przestrzega przed „medycyną Hildegardy”. Autor strony twierdzi, że ten termin został sformułowany po raz pierwszy na rosnącej fali popularności ezoteryki i New Age'u:

Hildegarda od razu została wykorzystana w celach handlowych, a istotą promocji było podkreślanie szczególnych wartości płynących z jej stosowania - medycyna ta miała bowiem pochodzić z boskiego objawienia (stąd określenie: „boska medycyna”). W rzeczywistości Hildegarda zapisała i przetworzyła zebraną przez siebie wiedzę medyczną, która funkcjonowała w XII wieku. Pisma, które zostały odnalezione na początku XX wieku w Kopenhadze pochodzą z XIII i XIV wieku. Są one zbiorem tekstów o charakterze przyrodniczym i medycznym, opatrzonymi nazwiskiem Hildegardy (w rzeczywistości są one po prostu opatrzone jej nazwiskiem, praktyka taka była powszechna w średniowieczu ${ }^{25}$.

${ }^{25}$ Medycyna Hildegardy, <http://zagrozeniaduchowe.pl/?p=376>, [data dostępu: 17.04.13]. 
Dalej możemy przeczytać, że z punktu widzenia dzisiejszej medycyny dzieła Hildegardy są zupełnie nieprzydatne i przestarzałe, a w niektórych aspektach (oddziaływanie kamieni) - zabobonne. Nie wiadomo do końca, czy autor tej strony przestrzega przed New Age'em czy może przed samą Hildegardą, podważając wartość (także chrześcijańską) jej dzieł. Zauważyć trzeba tutaj sprzeczność, ponieważ wszystkie książki lecznicze i zielarskie oparte na jej naukach można kupić w księgarniach katolickich. Ten przykład ukazuje aktualny problem - pomimo uznania Hildegardy za świętą i nadania jej tytułu doktora Kościoła budzi ona nadal wiele kontrowersji. Niesłuszne oskarżenia Hildegardy o magię i odrzucanie jej nauk o kamieniach szlachetnych czy wpływie faz Księżyca na człowieka wynika z niewiedzy na temat epoki średniowiecza i z niezrozumienia tego, jak wyglądał ówczesny świat i ludzie ${ }^{26}$.

${ }^{26}$ Zob.: C.S. Lewis, Odrzucony obraz. Wprowadzenie do literatury średniowiecznej i renesansowej, thum. W. Ostrowski, Warszawa 1986, s.183-187. 


\section{HILDEGARDA - ŚREDNIOWIECZNA MNISZKA W DYSKURSIE FEMINISTYCZNYM}

Kształt kobiety rozbłysnąt i zajaśniat w pierwszym promieniu, w którym zostało ukształtowane to, w czym kryje sie wszelkie stworzenie. Jak? Podwójnie: przez doskonate dzieło palca Bożego i przez najwyższe piękno ${ }^{27}$.

Dzięki zainteresowaniu się tematyką kobiet w średniowieczu i powstaniu $\mathrm{w}$ ostatnich dziesięcioleciach wielu prac na ten temat oświeceniowa i romantyczna wizja tej epoki powoli się zmienia. Pierwszy pogląd rozpowszechniał wiedzę o „ciemnym” średniowieczu i twierdził, że w tym okresie kobieta była pojmowana tylko jako źródło grzechu, toteż w pełni odsuwano ją od dóbr kultury. W przypadku, gdy umiała pisać lub czytać, służyło jej to tylko po to, by mogła się modlić i podpisywać listy. Romantyczne wyobrażenie mówiło zaś o tym, że wkład kobiety w kulturę był bierny, polegał tylko na inspirowaniu artystów. Następny stereotyp, z którym można się jeszcze spotkać, to z kolei przeświadczenie o istnieniu wielkiej pogardy dla kobiet w literaturze tego okresu.

Magdalena Sakowska w książce Portret, postać, autorka. Kobieta a literatura europejskiego średniowiecza udowadnia, że aktualne badania wykazują brak mizoginii w literaturze średniowiecza ${ }^{28}$. Negatywne wartościowanie kobiet i wywyższanie mężczyzn nie było głównym tematem rozpraw, czasami ten temat przemilczano bądź wręcz pisano o kobietach pozytywnie.

${ }^{27}$ Hildegarda, Hildegarda do kongregacji mniszek, [w:] B. Matusiak, Teologia muzyki, Tyniec 2003, s.187.

${ }^{28}$ M. Sakowska, Portret, postać, autorka. Kobieta a literatura europejskiego średniowiecza, Warszawa 2006, t.1, s. 7. 
Kwestia miejsca kobiety w średniowieczu budziła i budzi ogromne emocje, co powoduje, że wiele opracowań balansuje na granicy obiektywizmu naukowego, przechylając się niebezpiecznie w stronę jednej lub drugiej skrajności: charakterystycznego dla dawniejszych czasów uporczywego zaprzeczania, że kobieta miała jakikolwiek znaczący wpływ na kulturę tamtych stuleci, i nowszej tendencji, opartej niekiedy na nadmiernym entuzjazmie i euforii w odkrywaniu trendów nieznanych dotąd w nauce ${ }^{29}$.

Według Magdaleny Sakowskiej remedium na rozwiązanie problemów wynikających z dwóch przeciwstawnych sobie spojrzeń na średniowiecze jest stworzenie dyskursu opisującego zarówno negatywne, jak i pozytywne strony tej epoki. W wyżej wymienionej pracy autorka zanalizowała 33 postacie kobiece, głównie występujące w kronikach i literaturze dwornej. Tylko w sześciu dziełach Magdalena Sakowska znajduje mizoginizm, a w ośmiu - kobietę przedstawioną jako odpowiedzialną za zły rozwój wypadków. W niektórych tekstach kobieta jest ,równie wartościowa co mężczyzna, aktywna, pełna godności, obdarzona wieloma zaletami, władzą, autorytetem, mądrością"30. Oczywiście badaczka jest świadoma, że literatura nie daje pełnego obrazu pozycji kobiety w średniowieczu. Jednak to właśnie z dzieł pisanych czerpiemy wiedzę o tamtym wiekach.

Oprócz samych wyobrażeń kobiecych w literaturze, mamy dzisiaj wiedzę o istnieniu szeregu kobiet liczących się w kulturze czy w życiu społecznym średniowiecza. Hildegarda była więc jedną z pierwszych kobiet piszących $\mathrm{w}$ tej epoce, ale nie jedyną.

Mechtylda z Hackebornu, Gertruda Wielka, Mechtylda z Magdeburga, Małgorzata Ebner z Medingen, Krystyna Ebner z Engeltal, Elżbieta Stagel, Julianna z Norwich, Julianna z Mont-Cornillon - to przykłady innych zakonnic i autorek, których doświadczenie mistyczne zostało wyrażone w pismach,

\footnotetext{
${ }^{29}$ Ibidem.

${ }^{30}$ Ibidem.
} 
utworach muzycznych i plastycznych. Są one świadectwem udziału kobiet w kulturze wieków średnich. W klasztorach mniszki przyczyniały się do rozwoju nowych form wypowiedzi artystycznych, literackich, muzycznych oraz plastycznych.

Tymczasem dzisiaj, w wyniku braku wiedzy o wiekach dawanych i pozycji kobiety w ówczesnym życiu politycznym, kulturalnym i religijnym, powszechnie uważa się, że dopiero od XVIII wieku można mówić o początkach wolności kobiet. Korzenie feminizmu dostrzega się we Francji i w Rewolucji Francuskiej 1789 roku.

W okresie trzeciej fali feminizmu kobiety zaczęły szukać wzorów w poprzednich epokach. I tak za protofeministkę uważa się francuską pisarkę żyjącą w XIV wieku - Christine de Pisan, która otwarcie krytykowała dominację mężczyzn i promowała aktywność kobiet w sztuce, nauce i życiu politycznym.

Okazuje się, że również Hildegarda została uznana za feministkę, stając się w latach 80. wzorcem dla teologii feministycznej w Stanach Zjednoczonych. Zainteresowano się jej niezwykłym życiem, podróżami, wykładami, które odbywała, kontaktami i sporami z ważnymi postaciami, bogatą twórczością naukową i artystyczną oraz autorytetem i władzą, jaką sprawowała nad klasztorami. W średniowieczu, postrzeganym jako okres ucisku kobiet, odnaleziono Hildegardę, która nie poddała się kulturze patriarchalnej. Trzecia fala feminizmu spowodowała gwałtowny rozwój badań nad twórczością Hildegardy. W publikacji Please don't talk about Hildegard and feminist in the same breath Lorny Collingridge pisze o wpływie badań feministycznych na rozwój studiów nad Hildegardą. Jej zdaniem wielu badaczy przeciwnych temu ruchowi boi się przyznać zasługi w tej kwestii badaniom feministycznym. W ich rozumowaniu perspektywa feministyczna zakładałaby, że:

- Hildegarda była uciskana przez mężczyzn i świadomie się temu sprzeciwiała, była więc protofeministką; 
- Hildegarda była lesbijką, ze względu na jej publiczne deklaracje miłości do mniszki Ryszardy, swojej uczennicy i podopiecznej;

- Głównym problemem, jakim zajmowała się Hildegarda była równość kobiet i mężczyzn.

Autorka artykułu zamieszcza interesującą tabelkę, z której można wyczytać, w jakich latach i ile powstawało publikacji o XII-wiecznej mniszce. Wynika z niej, iż to właśnie w latach 1980-90 zaobserwowano ożywienie w badaniach nad Hildegardą. Nowe spojrzenie na Hildegardę, w kontekście studiów feministycznych, przyniosło osiem publikacji w języku angielskim i jedną w niemieckim. Lata 1990-2000 to już ogromny skok w zainteresowaniu tą świętą - powstało 50 pozycji w języku angielskim, dwie w niemieckim i dwie we francuskim. Wszystkie te publikacje były owocem nowych studiów nad twórczością kobiet.

Nadal duża część badaczy nie chce wiązać Hildegardy z feminizmem, np. zdaniem teologów Elżbiety Wiater oraz Jerzego Strzelczyka nazywanie Hildegardy feministką jest ogromnym nadużyciem i nieporozumieniem. Przypominają oni, że Hildegarda wielokrotnie pisze o sobie jako o słabej kobiecie i podkreśla niższość kobiety względem mężczyzny.

Tymczasem prawdą jest, że zarówno w twórczości, jak i w życiu codziennym Hildegarda nie bała się mówić i pisać o kobietach.

Frances Beer podkreśla, że:

w jej dziele występuje szereg potężnych postaci rodzaju żeńskiego, takich jak Sapientia (Mądrość), Synagoga (Matka Wcielenia Słowa Bożego), Ecclesia (Kościół), które realizują boży plan na ziemi. Chociaż są to alegorie, ich żeńskość to nie tylko gramatyczne przypadki. Ich kobiecość jest wyraźnie podkreślana przez wzmianki o piersiach, łonach i o tak specyficznych kobiecych funkcjach, jak wydawanie na świat dzieci i karmienie potomstwa $^{31}$.

${ }^{31}$ F. Beer, Kobiety i doświadczenia mistyczne w Średniowieczu, thum. A. Branny, 
W księdze drugiej Scivias znajdziemy opis Kościoła - jako Mądrości w postaci pięknej kobiety:

Jej spojrzenie ogarnia świat i zwraca się do ludzi. Jej głowa owinięta blaskiem, oświetlona jakby lampą, tak że nie mogłam dojrzeć jej w całej krasie. Jej ręce z szacunkiem spoczywają na piersi. Jako strój nosiła płaszcz złoty, ze stułą zdobną w drogocenne klejnoty - białe, zielone, czerwone i złote, przeniknięte purpurowym światłem. I ludziom całego świata rzekła głosem wielkim: „Dlaczego ociągacie się z przyjściem? Nie wierzycie, że u mnie znajdziecie pomoc? [...]"32.

Opisanie w ten sposób Kościoła - Mądrości, jest wyrazem ogromnego szacunku dla kobiet. Innym razem w wizjach mniszki Kościół jest oblubienicą oraz matką (dziewicą jak Maryja). W symbolicznym języku Hildegardy trzykrotnie pojawia się postać wspaniałej kobiety: w stanie dziewictwa, kapłaństwa i świeckości. Benedyktynka dostrzega piękno każdej kobiety, chociaż w szczególności wyróżnia dziewice.

Prawdziwym świadectwem myśli Hildegardy o kobietach są teksty antyfon, m.in. o Maryi Dziewicy ${ }^{33}$ :

$\mathrm{O}$, wielki to cud, że skrycie w ciało niewiasty

król wkroczył.

Bóg to sprawił,

bo niższość nade wszystko jest wywyższona.

Och, jakże wielka jest szczęśliwość

w tej niewieście

bo zło, które z niewiasty się wzięło, ona zmazała.

Nagromadziła cnoty słodyczą wionące

I Niebo ustroiła jeszcze nadobniej,

Kraków 1996, s.17.

${ }^{32}$ G. D. Croce, Symbolizm kobiecy u Hildegardy z Bingen [w:] Geniusz kobiecy, Kraków 2011, s. 56.

${ }^{33}$ S. Flanagan, Hildegarda z Bingen, tłum. R. Sudół, Warszawa 2002, s.125. 
Niźli gdy pierwej ziemię poślubiła.

Hildegarda pisze o niższości kobiet i o grzechu, który z nich pochodzi, dziwi się, w jaki sposób Bóg urodził się z niewiasty. Jednak ta niższość, zapoczątkowana przez Ewę, pod piórem benedyktynki zostaje wywyższona, zrehabilitowana przez Maryję.

Hildegarda usprawiedliwia grzech Ewy. Widzi w niej „Dziewicę obleczoną w słońce” (Ap 12,1). Według niej Szatan postanowił skusić pierwszą kobietę, bo bał się, że będzie matką wojowników walczących przeciw niemu. Tłumacząc, dlaczego Szatan zwiódł Ewę, Hildegarda podkreśla jej piękno oraz wzajemną miłość pierwszych rodziców:

Diabeł wiedział, że łatwiej pokona niewieścią słabość, niż siłę męża, a wiedząc, że Adam płonie mocną miłością do Ewy, pomyślał, że jeżeli ją pokona, Adam uczyni wszystko co ona mu powie ${ }^{34}$.

W pieśniach mistyczki Ewa często porównywana jest do Maryi, nazywanej nową Ewą. W sekwencji $O$ virga ac diadema ${ }^{35}$ znajdziemy słowa, które mówią o kobiecie, która jest zwierciadłem Bożego piękna i mikrokosmosem. Cechy, które w innych dziełach Hildegarda przypisywała Adamowi, teraz odnoszą się do kobiet. Tym samym mniszka podkreśla równość, jaka jest między dwoma płciami, każdy człowiek jest odbiciem Boga i świata.

Miniatury znajdujące się w pismach Hildegardy interpretuje Frances Beer. Jedną z nich, z wizji pierwszej i drugiej Scivias, widzi jako wszechświat żeńskie jajo:

${ }^{34}$ B. Matusiak, Teologia ..., op. cit., s. 96.

${ }^{35}$ Ibidem, s. 107. 
Do najbardziej zaskakujących przedstawień boskości, jakie spotykamy u Hildegardy, należy ogromne, wypełnione gwiazdami, ogniste kosmiczne jajo - gigantyczny, wszechogarniający symbol żeński3 ${ }^{36}$.

Inna miniatura pochodzącą także ze Scivias, w której jest obecna kobieca alegoria, to ilustracja z księgi drugiej i trzeciej ${ }^{37}$. Przedstawia ona Kościół (Eklezję) jako Matkę wierzących. Miniatura podzielona jest na cztery części. $\mathrm{Na}$ iluminacji widnieje kobieta w kolorze złotym, z długimi włosami i koroną na głowie. $Z$ polecenia Chrystusa rodzi ona dzieci Kościoła.

Trzeba jednak pamiętać, że symbolizm kobiecy nie jest pomysłem Hildegardy ani nie jest czymś nowym w chrześcijaństwie. Wszystkie żeńskie alegorie były obecne od wieków, Hildegarda zaś zaczerpnęła je z Nowego i Starego Testamentu. Brak wiedzy o tym, czym była alegoria, może doprowadzić do błędnych wniosków o poglądach Hildegardy. Wykorzystywanie postaci kobiet w przedstawieniach alegorycznych było wówczas czymś zupełnie normalnym ${ }^{38}$.

Święta z Bingen jest także prekursorką pisania dzieł z zakresu medycyny dla kobiet. W swoich pracach opisuje wszystkie schorzenia kobiece i sposób ich leczenia. Ponadto wyróżnia cztery temperamenty człowieka, w tym kobiet (melancholiczka, sangwiniczka, choleryczka, flegmatyczka) i dokładnie charakteryzuje je, podając przyczyny chorób. „Hildegardy opis temperamentów jako źródła patologii seksualnej różni się jednak od tradycji medycznej i jest kluczem do zdrowia kobiety, właściwego wyboru partnera, jej zdolności kochania, a nawet cech spłodzonych dzieci”39.

${ }^{36}$ F. Beer, Doświadczenie ..., op. cit., s.17, zob.: miniatura nr 1.

${ }^{37}$ Zob.: miniatura nr 2.

${ }^{38}$ Patrz: C. Ripa, Wstęp, [w:] idem, Ikonologia, tłum. I. Kania, Kraków 1992, s. 5. Zob. termin alegoria w Encyklopedii PWN: ,[gr. allègoría < allēgorein 'mówić w przenośni', 'obrazowo'], lit., szt. plast. w literaturze i sztuce obraz mający poza znaczeniem dosłownym określony sens przenośny”.

${ }^{39} \mathrm{~W}$. Strehlow, Wiedza lecznicza św. Hildegardy z Bingen od A do Z, thum. E. Panek, Kraków 2010, s. 60. 
W Cause de curae Hildegarda odważnie charakteryzuje kobiece pożądanie i jego znaczenie przy poczęciu:

Kobiece pożądanie można porównać do słońca, które delikatnie, lekko i dokładnie oblewa ziemię swoim ciepłem, by mogła wydać owoce; albowiem, gdyby czyniło to zbyt intensywnie, zamiast pomóc $\mathrm{w}$ dojrzewaniu owocu, spaliłoby go. Tak więc kobiece pożądanie jest delikatne i lekkie, lecz stałe w swym cieple, czyniąc kobietę zdolną do poczęcia i urodzenia dziecka. Gdyby zaś trawiła ją wciąż gorączka pożądania, nie byłaby gotowa począć i dać życie dziecka. Kiedy w kobiecie rodzi się pożądanie, jest ono łagodniejsze i płonie mniej intensywnie niż w mężczyźnie ${ }^{40}$.

O zwyczajach panujących w klasztorze świętej Hildegardy dowiadujemy się z listu od mistrzyni Tenxwindy:

Dotarła również do nas wiadomość o pewnym Waszym osobliwym zwyczaju, że mianowicie Wasze Dziewice, gdy dni świąteczne stoją w kościele i śpiewają psalmy, włosy mają rozpuszczone, a za ozdobę służą im białe jedwabne szaty sięgające do ziemi. Na głowach noszą złote korony krzyżami po bokach i z tyłu, z przodu zaś koron wyryto pięknie postać Baranka. Ponadto na palcach mają złote pierścienie ${ }^{41}$.

Przełożona klasztoru kanoniczek w Andernach niepokoi się nietypowymi zachowaniami w klasztorze Hildegardy. Uważa, że eksponowanie włosów i noszenie pięknych szat przez niewiasty jest niezgodne z naukami Biblii. Zarzuca także mistyczce przyjmowanie nowicjuszek wyłącznie ze szlachetnych rodów.

Odpowiadając na ten list, Hildegarda opisuje miejsce i rolę kobiety. W chwili stworzenia została ona wywyższona przez swoje piękno i dzieło Boga. Jednak piękno może być zagrożeniem, dlatego kobieta nie powinna

${ }^{40}$ Hildegarda z Bingen, Cause de curae, [w:] J. Strzelczyk, Pióro w wattych dtoniach. O twórczości kobiet w dawanych wiekach, Warszawa 2009, t. 2, s. 242.

${ }^{41}$ Hildegarda, Mistrzyni Tenxwinda do Hildegardy, [w:] B. Matusiak, Teologia..., op. cit., s 183. 
chwalić się swoją urodą, chyba że z woli męża. To przykazanie nie dotyczy dziewic. Rozpuszczone włosy oznaczają viriditas, powrót do rajskiego $\operatorname{stanu}^{42}$. Hildegarda zaleca dziewicom, żeby nosiły białe szaty, jako znak zaślubin z Chrystusem, nie zachęca do próżności, lecz radości z piękna danego od Boga. Dalsza część listu jest jeszcze bardziej enigmatyczna i przypomina wizje, co potwierdzają ostatnie dwa zdania: „To powiada żyjące światło, a nie człowiek. Kto słyszy, niech widzi i niech wierzy, skąd pochodzą te słowa" ${ }^{\prime 3}$.

Hildegarda jeszcze raz powtarza, że słowa, które wypowiada, nie pochodzą od niej samej, lecz od samego Boga.

O stosunku Hildegardy do kobiet pisze Małgorzata Borkowska w najnowszej publikacji Od Radegundy do Julianny ${ }^{44}$ :

Zamiast wdrażać mniszki do poczucia niższości, obowiązującego wszędzie i zawsze [...], Hildegarda tak w swoich wizjach, jak i w pouczeniach najwyraźniej przedstawia kobiecość jako dobrą i w stosunku do mężczyzn równowartościową formę człowieczeństwa. Zamiast przygnębiać mniszki świadomością grzechu, uczy je radości płynącej z triumfu Boga. W święto chce nawet ubierać na biało, żeby czuły się tym radośniej. Powinny śpiewać z radości - zamiast płakać, czego przecież uczy tradycja monastyczna!

Hildegarda odbyła cztery podróże kaznodziejskie, nie tylko po klasztorach, ale też po wsiach i miastach. Nauczanie było czymś nietypowym dla kobiet w tamtych czasach. Mniszka wielokrotnie odnosiła sukcesy w rozmowach, czy to z przełożonymi zakonu, czy z wyższymi dostojnikami. Przykładem może być jej decyzja o samodzielnej przeprowadzce wspólnoty żeńskiej

${ }^{42}$ U Hildegardy termin ten oznacza pierwotną zieloność, świeżość, płodność, piękno, harmonie, pełnię życia. Termin ten znajdziemy m.in. w odpowiedzi na list Tenxwindy.

${ }^{43}$ Ibidem, s. 187.

${ }^{44}$ M. Borkowska, Od Radegundy..., op. cit., s. 88. 
i autonomii, jaką dzięki niej zyskała oraz niezgoda na przeniesienie grobu heretyka z przyklasztornego cmentarza.

Osoby znające Hildegardę nazywały ją Sybilla Renu, gdyż służyła radą największym postaciom swojej epoki, królom, książętom, papieżom, teologom. Byli wśród nich m.in.: Fryderyk Barbarossa, Hugon z klasztoru Świętego Wiktora, Gerhoh z Reichersbergu, Rupert z Deutz, Bernard z Clairvaux. Mistyczka włączała się w debaty społeczne, otwarcie nie zgadzała się z polityką Fryderyka Barbarossy - całkowitego podporządkowania Kościoła cesarstwu i winiła cesarza za sprzyjanie schizmatykom. W liście do Fryderyka straszyła go nawet apokaliptycznymi wizjami. „Ani przedtem, ani wtedy, ani potem nie znalazł się żaden mężczyzna, jakiejkolwiek godności czy rodu i jakikolwiek by piastował urząd, który prędzej czy później nie skapitulowałby przed Hildegardą. Dyskutować z nią lub nawet postąpić wbrew jej zdaniu zdarzało się czasami (rzadko) tylko kobietom" ${ }^{45}$.

Nietypową dla kobiet praktyką było odprawianie egzorcyzmów. Z Żywota napisanego przez Godfryda i Teodoryka dowiadujemy się, że Hildegarda uczestniczyła w tym rytuale nad kilkoma opętanymi kobietami.

Niewątpliwie badania feministyczne przyczyniły się do większego zainteresowania Hildegardą, jednak z wyżej wymienionych przykładów z jej życia i twórczości wynika, iż z pewnością nie była ona feministką w dzisiejszym rozumieniu tego terminu.

Hildegarda nie wywyższała kobiet, nie próbowała udowodnić, że kobieta powinna odgrywać takie same role jak mężczyzna. Natomiast zgodnie z jej teorią mikrokosmosu i harmonii uważała, że każdy człowiek jest odbiciem Boga. Z tego też powodu każda osoba, bez względu na płeć, odznacza się wielką godnością. W jej oczach kobieta jest tak samo cenna jak mężczyzna. Hildegarda nie czuła potrzeby ciągłego dorównywania mężczyznom, bo była świadoma swojej wartości danej od Boga. Mniszka wyznawała wiarę

${ }^{45}$ Ibidem, s. 88-89. 
w Stwórcę, który jest Miłością, a ta miłość dotyczy w tym samym stopniu kobiety i mężczyzny. Miłość nie stawia granic, ale daje możliwość rozwoju zarówno duchowego, jak i intelektualnego.

Hildegarda nie stroniła od mężczyzn, wręcz przeciwnie, jej największym przyjacielem był Wolmar, któremu powierzała swoje wizje. Całe życie była wierna instytucji kościelnej i za każdym razem pokornie przyjmowała jej nakazy. Siła, którą miała, wypływała przede wszystkim z duchowości, z pewności, że to, co robi jest misją daną od Boga. Z tej przyczyny mogła, a wręcz musiała się czasami buntować, by wypełnić Boży nakaz. „Wydaje się, że Hildegarda największą swoją siłę czerpała paradoksalnie z własnej słabości. Uznając ją pozwoliła Bogu siebie swobodnie prowadzić"46.

Te słowa należy rozumieć nie jako uznanie słabości wobec mężczyzn, ale względem samego Boga. Hildegarda miała świadomość małości człowieka (mężczyzny i kobiety) i wszechmocy Boga, dlatego wielokrotnie pisała o sobie jako o istocie słabej.

Paradoksalnie dzisiaj powszechne jest myślenie według zasady: im dawniejsza epoka, tym gorsza sytuacja kobiet. Okazuje się jednak, że w czasach średniowiecza kobiety miały większy wpływ na kulturę czy życie społeczno -polityczne niż np. po Rewolucji Francuskiej, która potraktowała je w sposób okrutny, lub w wieku XIX, kiedy w wielu krajach zgodnie z obowiązującym Kodeksem Napoleona kobiety były praktycznie ubezwłasnowolnione. Powyższy pogląd o wiekach dawnych wynika z istniejących społecznie stereotypów. Stereotypy te zaś wypływają z niewiedzy.

We współczesnej kulturze Hildegarda jest interesująca zarówno dla teologów, jak i filozofów, lekarzy, muzykologów, muzyków, ekologów, feministek i zwolenników New Age. Nie powinno to wywoływać w nas zdziwienia. Mniszka zajmowała się wszystkimi możliwymi aspektami związanymi

${ }^{46}$ W. Strehlow, Wiedza lecznicza św. Hildegardy z Bingen od a do Z, thum. E. Panek, Kraków 2010; E. Wiater, Hildegarda z Bingen, Kraków 2012, s.124. 
z człowiekiem. Zgłębiała wiedzę przyrodniczą, medyczną, teologiczną i muzyczną. Dostrzegała Boga zarówno we wszystkich przejawach natury, jak i w możliwościach twórczych człowieka. Nie izolowała Stwórcy i kosmosu od potomków Adama i Ewy. Wręcz przeciwnie, pokazywała, czego potrzebuje człowiek, aby żyć w harmonii ze światem i osiągnąć szczęście.

Fenomen średniowiecznej mniszki, która stała się autorytetem w XXI wieku, jest dość zaskakujący, jednak ma swoje wytłumaczenie. Hildegarda, otwarta na człowieka i jego potrzeby (rozwój duchowy i intelektualno-artystyczny, zdrowie fizyczne i psychiczne), wzór silnej i w dużym stopniu niezależnej kobiety, idealnie odpowiada poszukiwaniom i potrzebom współczesnego człowieka. W dzisiejszej kulturze powstaje mnóstwo organizacji ekologicznych i zdrowego sposobu życia. Wiele osób interesuje się duchowością, religiami i filozofią Wschodu (np. ruch New Age). Wyraźnie więc można zaobserwować potrzebę życia w harmonii, zgodnie ze sobą i z naturą.

Niestety, zainteresowanie Hildegardą łączy się także z manipulacją. Mniszka stała się dobrze sprzedającym się produktem konsumpcyjnym. Niektóre sklepy wykorzystują jej popularność do etykietowania swoich produktów, które nie mają nic wspólnego ze świętą. Kultura New Age interpretuje jej nauki na własne potrzeby, a feministki przypisują jej swoje poglądy. Z drugiej strony niektóre jej nauki są odrzucane i traktowane jako zabobonne. 
Niniejszy artykuł jest fragmentem pracy licencjackiej zatytułowanej Św. Hildegarda z Bingen - średniowieczna feministka a wspótczesna Doktor Kościoła, powstałej pod kierunkiem dr Joanny Pietrzak-Thebault. Praca jest dostępna w archiwum Uniwersytetu Kardynała Stefana Wyszyńskiego.

\section{Image of Holy Hildegard of Bingen in Contemporary Culture}

The article St. Hildegard of Bingen in Contemporary Culture was based on fragments of Licence Work.: St.Hildegard of Bingen - medival "feminist" and contemporary doctor of Church. The author concentrates on great interest of Saint Hildegard - the most interesting and best known monk of medieval ages. Saint Hildegard is a authority and inspiration for many different societes generating discussions. This work tries to answer questions on manipulation and use of Hildegard by contemporary culture. It also underlines stereotypes of thinking about medival ages and position of women in Church.

Keywords: Hildegard of Bingen, the medieval feminist, feminism in the Church, the woman in the Church, Doctor of the Church, Hildegard in culture. 


\section{SPIS FOTOGRAFII I MINIATUR}

\section{Miniatury:}

Źródła:

Nr 1 Wszechświat (jajo świata). Scivias, wizja 1, 3.

http://www.landderhildegard.de/ihr-leben/visionaerin-und-theologin/ scivias/

Nr 2 Kościół (Eklezja), Matka wierzących. Scivias 2, 3.

http://www.abtei-st-hildegard.de/wp2012/wp-content/uploads/2011/12/ Bildschirmfoto-2011-12-09-um-17.34.48.png

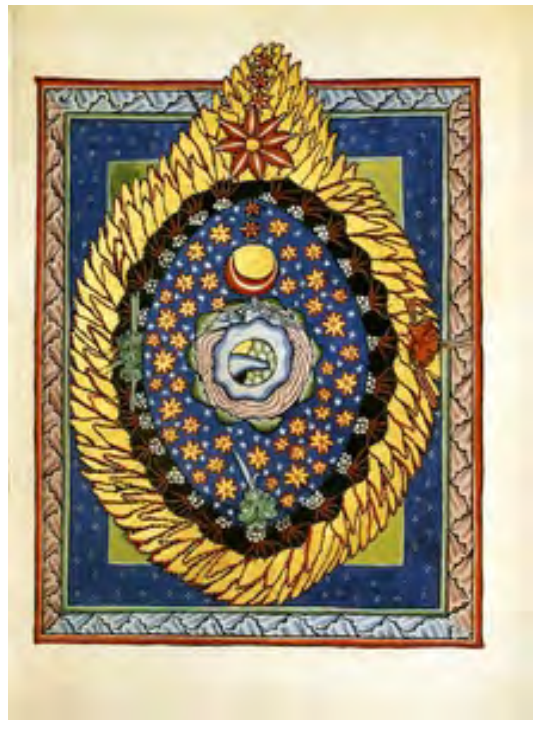

Nr 1

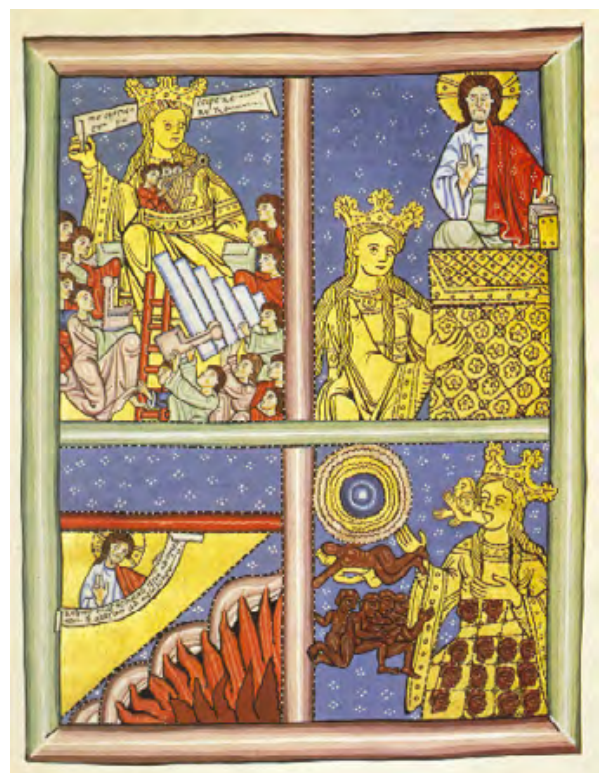

Nr 2 


\section{Fotografie}

Źródło:

\section{Nr 1: Wafle orkiszowe}

http://www.frisco.pl/pid,9802/n,SONNENTOR--Wa-

fle-orkiszowe-z-amarantusem-Sw-Hildegardy-BIO/

stn,product

Nr 2: Wino Scivias od św. Hildegardy http://sklep.hildegarda.pl/product. php?id_product $=459$

Nr 3: Ziolowa pasta do zębów winogronowa http://sklep.hildegarda.pl/ product.php?id_product $=323$

Nr 4: Krem antycellulitowy z szałwii

http://sklep.hildegarda.pl/product.php?id_product=140

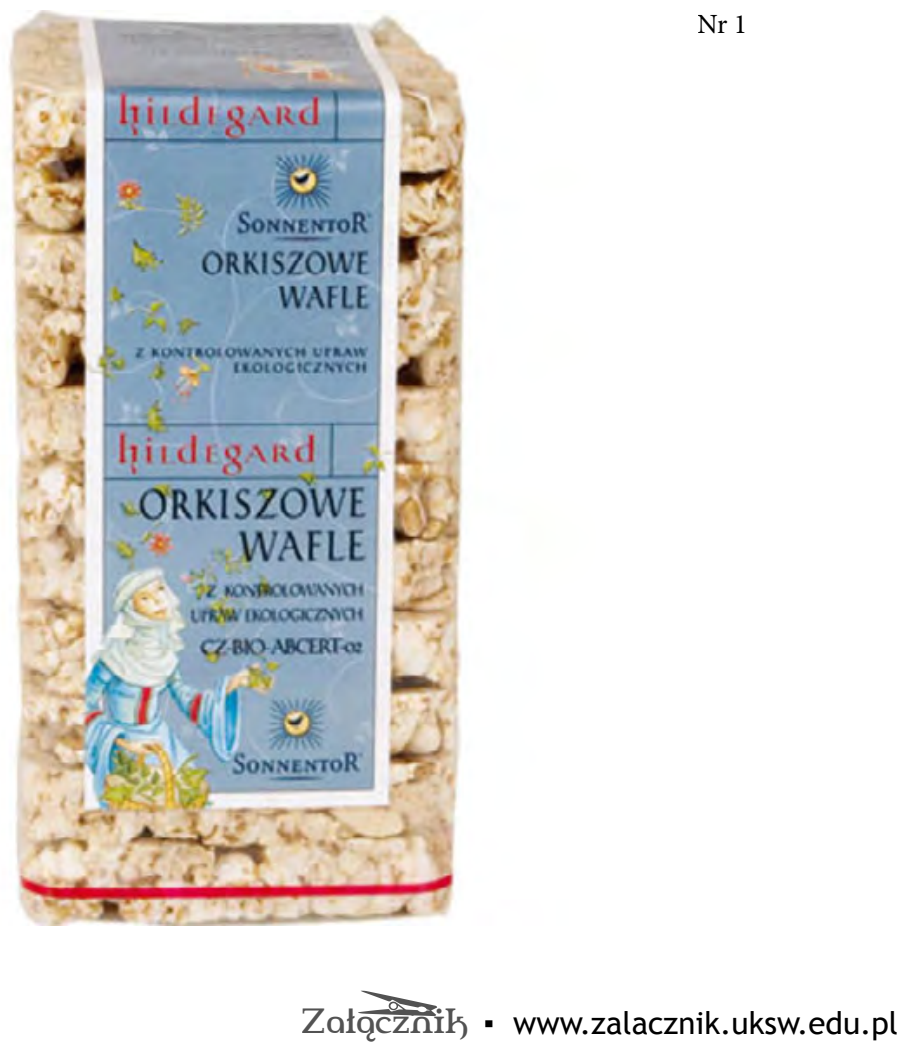


JOANNA TARNAWSKA

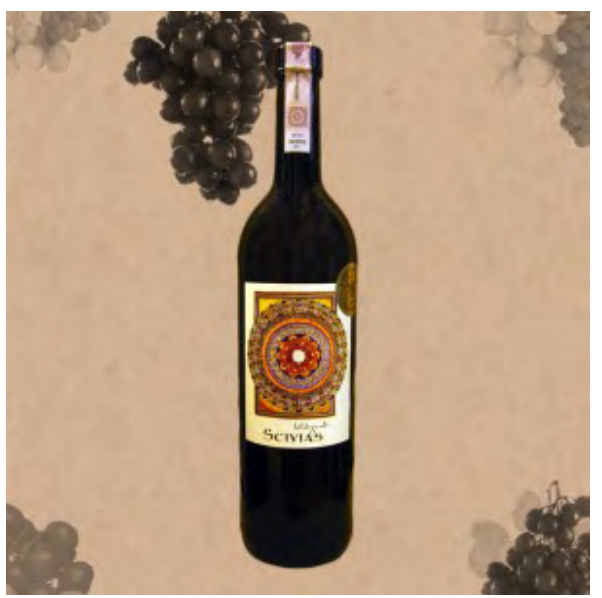

Nr 2

Nr 3
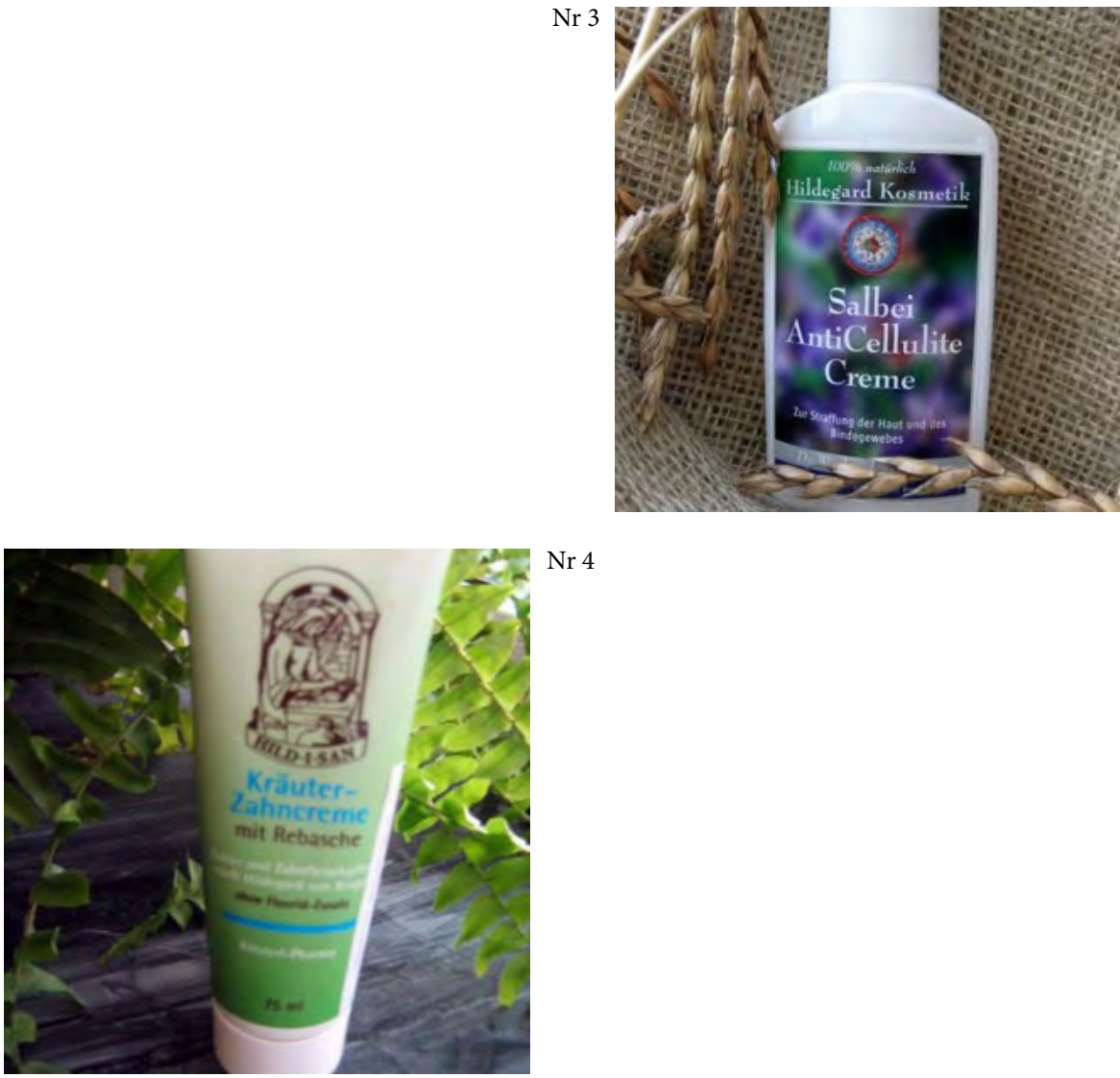

$\mathrm{Nr} 4$ 


\section{Wydawnictwo Uniwersytetu Kardynała Stefana Wyszyńskiego}

Polecamy ostatnio wydane publikacje
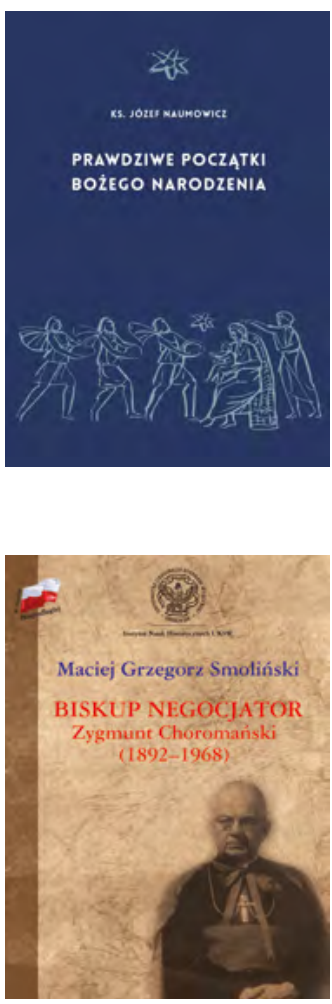

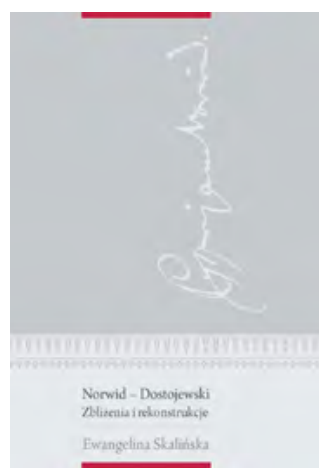

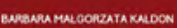

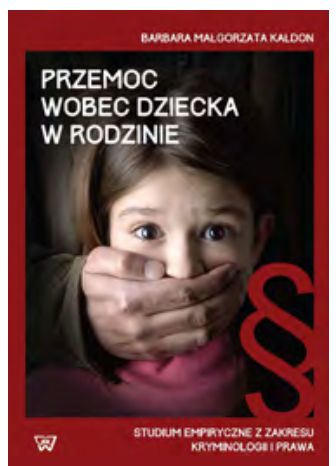

$W^{\text {ydawnictwo UKSW pu- }}$ blikuje książki naukowe i popularnonaukowe: monografie, rozprawy doktorskie i habilitacyjne, tomiki poezji, materiały pokonferencyjne, podręczniki i prace zbiorowe, o tematyce obejmującej wszystkie dziedziny, w których Uniwersytet Kardynał Stefana Wyszyńskiego prowadzi badania naukowe oraz kształcenie.

Wydawnictwo UKSW ul. Dewajtis 5, Warszawa tel. 225618838 